\title{
Will climate warming exceed lethal photosynthetic temperature thresholds of lichens in a southern African arid region?
}

\author{
Khumbudzo Walter Maphangwa, Charles F. Musil, Lincoln Raitt and Luciana Zedda
}

\begin{abstract}
Predicted elevated temperatures and a shift from a winter to summer rainfall pattern associated with global warming could result in the exposure of hydrated lichens during summer to more numerous temperature extremes that exceed their thermal thresholds. This hypothesis was tested by measuring lethal temperature thresholds under laboratory and natural conditions for four epilithic lichen species (Xanthoparmelia austro-africana, $X$. hyporhytida, Xanthoparmelia sp., Xanthomaculina hottentotta) occurring on quartz gravel substrates at a hot arid inland site two epigeous lichen species (Teloschistes capensis, Ramalina sp.) occurring on gypsum-rich topsoil at a warm humid coastal site. Extrapolated lethal temperatures for photosynthetic quantum yield under laboratory conditions were up to $4^{\circ} \mathrm{C}$ higher for lichens from a dry inland site than those from a humid coastal site. Lethal temperatures extrapolated for photosynthetic quantum yield at a saturating photosynthetic photon flux density of $\geq 11$, ooo lmol photons $\mathrm{m}^{-2} \mathrm{~s}^{-1}$ under natural conditions were up to $6^{\circ} \mathrm{C}$ higher for lichens from the dry inland site than the more humid coastal site. It is concluded that only under atypical conditions of lichen exposure in a hydrated state to temperature extremes at high midday solar irradiances during summer could lethal photosynthetic thresholds in sensitive lichen species be potentially exceeded, but whether the increased frequency of such conditions with climate warming would lead to increased likelihood of lichen mortality is debatable.
\end{abstract}

\section{Introduction}

The unprecedented accumulation of $\mathrm{CO}_{2}$ and other greenhouse gases in the atmosphere as pre-industrial times has already had a discernible influence on global temperature and is forecast to cause further warming this century (IPCC, 2007). Direct and dramatic biotic responses to global warming are anticipated (Thomas et al., 2004). This expectation is supported by new and increased occurrences of subtropical epiphytic lichen species in Europe, for example in the Netherlands where lichen species preferring colder environments have declined in numbers or disappeared between 1980 and 2001 (Aptroot \& van Herk, 2007). 
Lichens are recognized as valuable indicators of climate shifts, especially in temperature and precipitation (Insarov \& Insarova, 2002), but there are few data on climatic impacts on lichens in arid and semi-arid ecosys- tems in the southern hemisphere whose diversity is potentially threatened by global climate change, espe- cially in species-rich southern African regions (Zedda et al., 2011). An impact of climatic change on southern African lichens in the arid Succulent Karoo Biome could be a loss of rare and endemic species and a rapid colonization of substrata by globally widespread species, particularly cyanolichens. This will have potentially profound effects on this biome, which is characterized by an extraordinary and peculiar diversity of lichen taxa (Zedda \& Rambold, 2009).

Climate simulations for the southern African arid winter rainfall region predict a progressive extension of wetter summer rainfall and drier winter rainfall regions (MacKellar, Hewitson \& Tadross, 2007) accompanied by a mean annual air temperature increase of up to $5.5^{\circ}$ towards the end of this century (Hulme et al., 2001). These climatic changes could result in the exposure of hydrated lichens during summer to an increased incidence of temperature extremes that exceed their thermal thresholds.

\section{Methods and materials}

\section{Study sites and species}

Lichens were examined at two climatically and floristically diverse sites in the South African Western and Northern Cape Provinces. The first hot arid inland site with a mean annual temperature of $25.7^{\circ} \mathrm{C}$ and annual rainfall of $145 \mathrm{~mm}$ was the farm Quaggaskop $\left(31^{\circ} 24.6^{\prime} \mathrm{S}, 18^{\circ} 37.8^{\prime} \mathrm{E}\right)$ situated at an elevation \pm 160 $\mathrm{m}$ in the Knersvlakte bioregion $20 \mathrm{~km}$ north of the town of van Rhynsdorp (Fig. 1). The second warm humid coastal site with a mean annual temperature of $17.2^{\circ} \mathrm{C}$ and an erratic low rainfall of $39 \mathrm{~mm}$ per annum supplemented by frequent fog mea- sured at $214 \mathrm{~mm}$ per annum (Maphangwa et al., 2011) were a large lichen field $\left(28^{\circ} 37^{\prime} \mathrm{S}, 16^{\circ} 3 \mathrm{O}^{\prime} \mathrm{E}\right)$ situated south- east of the mining town of Alexander Bay, $3.2 \mathrm{~km}$ distant from the Atlantic coast (Fig. 2). The six selected study species were Xanthoparmelia austro-africana (Stirt) Hale, X. hyporhytida (Hale) Hale, Xanthoparmelia sp. (unde- scribed), Xanthomaculina hottentotta (Ach) Hale occurring on quartz gravel substrates at the Quaggaskop site and Teloschistes capensis (L.f.) Müll Arg and an undescribed Ramalina sp. (often regarded as $R$. capensis Th Fr) occurring on gypsum-rich topsoil at the Alexander Bay site. These four epilithic and two epigeous species were selected for being endemic to the region (Dodge, 1971; Hale, 1990) and for their foliose and fruticose growth forms, which are known to be most sensitive to increased aridness (Nash, 1996).

\section{Laboratory studies}

Thirty-five thalli of each of the six lichen species were collected on their original substrates from the two study sites. The 210 lichen thalli were transferred to a growth room and allowed to acclimatize for 8 days at $18^{\circ} \mathrm{C}$ day per $10^{\circ} \mathrm{C}$ night at a $16 \mathrm{~h}$ daily photosynthetic photon flux density (PPFD) 
of $300 \mathrm{lmol}$ photons $\mathrm{m}^{-2} \mathrm{~s}^{-1}$. During the acclimation period, the lichens were hydrated every second day by applying a fine distilled water mist spray to their thalli. Following acclimation, the hydrated lichen thalli were exposed in forced draft ovens for 2-h intervals to temperatures ranging from the laboratory ambient $24-48^{\circ} \mathrm{C}$ at $4^{\circ} \mathrm{C}$ intervals. The 2-h oven exposure periods corresponded with diurnal temperature maxima confined to 1 -h periods on either side of the solar noon. There were five replicated lichen thalli per species for each of the seven heat treatments.

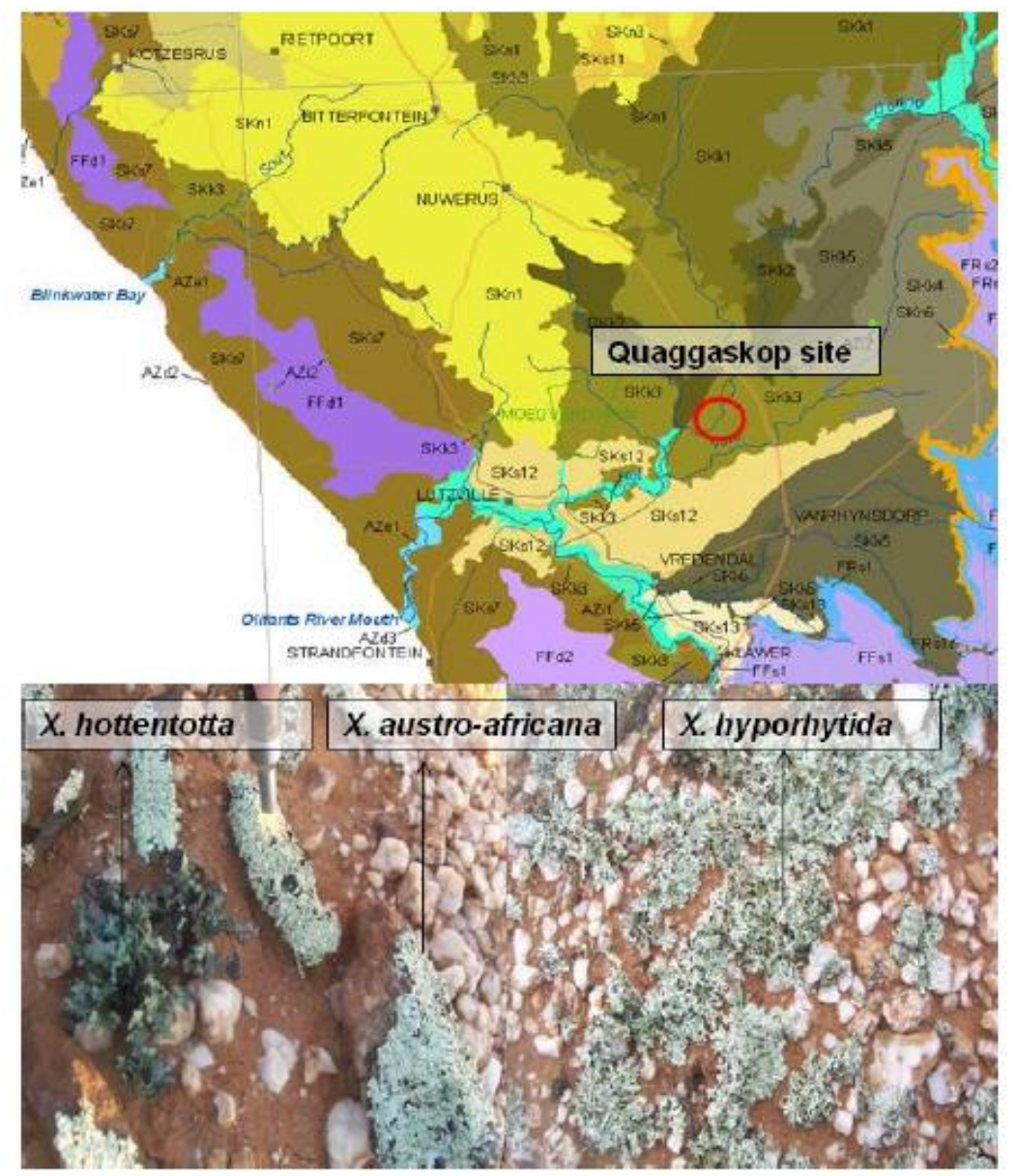

Fig 1 Location of the Quaggaskop experimental site and common lichen species occurring on quartz gravel substrates at the site

Following heat exposure, the lichens were returned to the growth room for an additional 24-h acclimation period after which they were rehydrated with a fine distilled water mist spray and allowed to drain for $1 \mathrm{~h}$ in the dark to avoid reported negative impacts of oversaturation by water on lichen photosynthesis, accord- ing to Lange, Belnap \& Reichenberger (1998). Subsequent measurements of initial $\left(F_{\mathrm{O}}\right)$ and maximal $\left(F_{\mathrm{m}}\right)$ fluores- cence emissions from the darkadapted, hydrated, heat- treated lichen thalli were taken with a Plant Efficiency Analyser (PEA; Hansatech Instruments Ltd., King's Lynn, Norfolk, UK) following a one-second PPFD of $3500 \mathrm{lmol}$ photons $\mathrm{m}^{-2} \mathrm{~s}^{-1}$. Three fluorescence measurements were performed on five thalli of each lichen species from each oven exposure temperature. Maximum quantum yields of Photosystem II (PSII) 
were computed from the ratios of variable to maximal fluorescence $\left(F_{\mathrm{V}} / F_{\mathrm{m}}=\right.$ $\left.F_{\mathrm{m}}-F_{\mathrm{O}} / F_{\mathrm{m}}\right)$.

\section{Field studies}

Demarcated plots $120 \mathrm{~cm}$ in diameter constructed from $40 \mathrm{~cm}$ high steel fencing with a five centimetre diameter mesh were installed at random over populations of the four epilithic lichen species at the dry inland site and popula- tions of the two epigeous lichen species at the more humid coastal site (six replicated plots per lichen species per site). Lichen thalli were hydrated with a fine distilled water mist spray and allowed to drain for a 1 -h period. Water saturation deficits were measured intermittently in ran- domly selected samples of lichen thalli $1 \mathrm{~h}$ after their artificial hydration using a published formula averaged $30 \pm 10 \%$ (Hảjek, Barták \& Gloser, 2001). These water saturation deficits were in the range of those at which maximum photosynthetic quantum yields have been reported in lichens with plateau and parabolic type photosynthetic responses to thallus dehydration (Hájek, Barták \& Gloser, 2001).

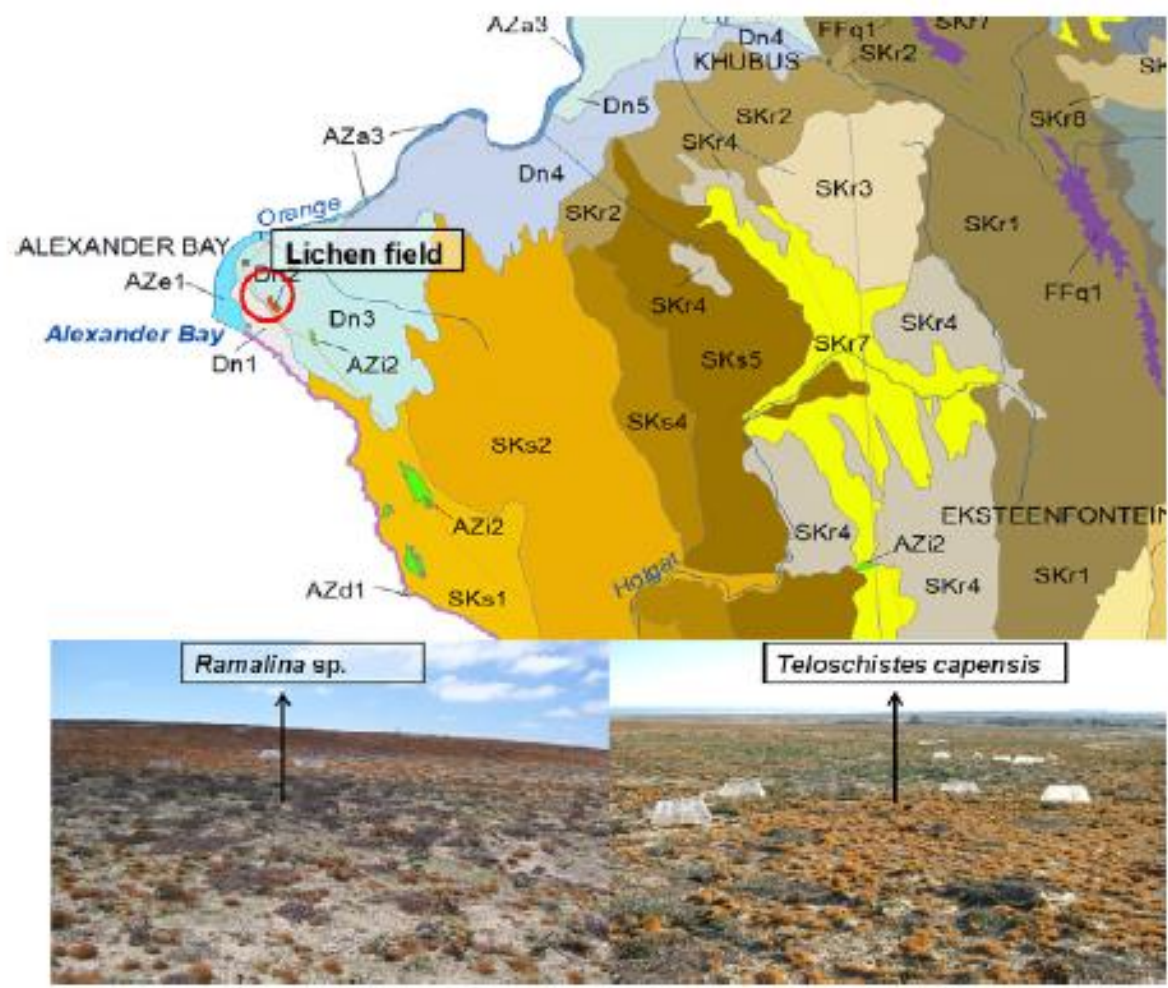

Fig 2 Location and typical lichen topography at the Alexander Bay experimental site

At monthly intervals, five replicated fluorescence measurements were taken hourly between 08 : oo and 17: oo with a portable modulated fluorometer (OSI-F1, Opti-Sciences Inc., Hudson, USA) on four randomly selected thalli of each lichen species at each site following their exposure to an $0.8 \mathrm{~s}$ saturating light pulse of 15, Ooo lmol photons $\mathrm{m}^{-2} \mathrm{~s}^{-1}$. Effective quantum yields of PSII ( $\left.\mathrm{D} F / F_{\mathrm{m}}{ }^{\prime}\right)$ were computed from ratios of variable steady state $\left(F_{\mathrm{ms}}-F_{\mathrm{S}}\right)$ to maximum steady- 
state $\left(F_{\mathrm{ms}}\right)$ fluorescence $\left(\mathrm{D} F / F_{\mathrm{m}}^{\prime}=F_{\mathrm{ms}}-F_{\mathrm{S}} / F_{\mathrm{ms}}\right)$. Fluorescence measurements were matched with simultaneously recorded ground surface air temperatures and PPFD using radiation-shielded thermocou- ples as described in Maphangwa et al., 2011.

\section{Statistical analyses}

The relationships between oven exposure temperature and measured $F_{\mathrm{V}} / F_{\mathrm{m}}$ in each lichen species were fitted using an iterative nonlinear regression applying an inverse mono-molecular function (Causton \& Dale, 1990)

$$
y=a\left(1-\mathrm{e}^{-b-c x}\right)
$$

where $y=F_{\mathrm{V}} / F_{\mathrm{m}}, x$ the oven exposure temperature with the coefficients a, b and $\mathrm{c}$ derived from the iterative process.

The reverse form of the inverse monomolecular function was applied to extrapolate at which lethal temperature $F_{\mathrm{V}} / F_{\mathrm{m}}$ attained zero:

$$
x=-\ln \{[(1-y / a) b] / c\}
$$

Least squares regressions quantified the relationships between field exposure temperature and measured $\Delta F / F_{\mathrm{m}}$ ' for each lichen species at a saturating PPFD ( $\geq 1100 \mu \mathrm{mol}$ photons $\mathrm{m}^{-2} \mathrm{~s}^{-1}$ ). A Student's $t$-test tested the slopes and the intercepts of the linear regressions for significance at $P \leq 0.001$. The regression equations were used to extrapolate the lethal temperatures at which $\Delta F / F_{\mathrm{m}}{ }^{\prime}$ attained zero.

\section{Results}

\section{Laboratory studies}

In all six lichen species, relationships between measured $F_{\mathrm{V}} / F_{\mathrm{m}}$ and oven exposure temperature quantified by the inverse monomolecular function (Fig. 3a) had coefficients of determination $\left(r^{2}\right)$ that were statistically significant at $P$ $\leq$ 0.001 (Table 1).

Extrapolated lethal photosynthetic temperatures for lichens from the dry inland site (range: $47.1-48.1^{\circ} \mathrm{C}$ ) were up to $4^{\circ} \mathrm{C}$ higher than those from the humid coastal site (range: $44 \cdot 1-44 \cdot 4^{\circ} \mathrm{C}$ ). 
(a)

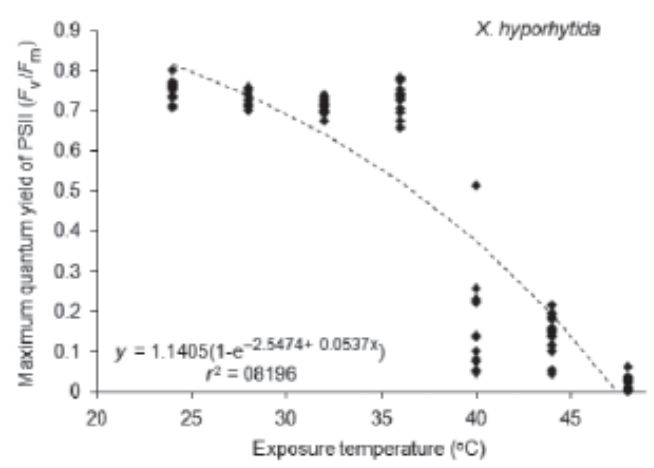

(c)

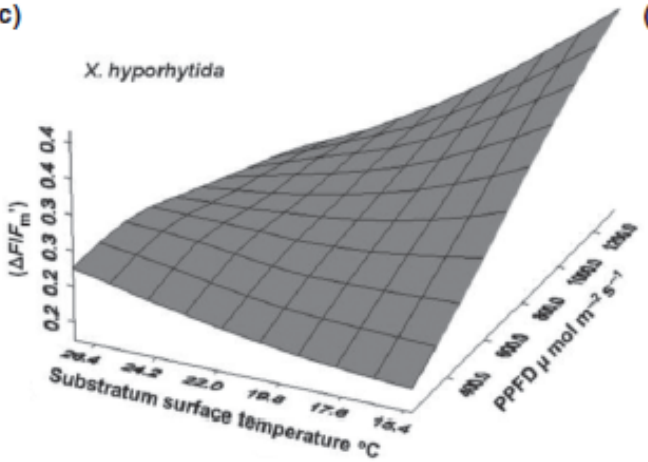

(b)

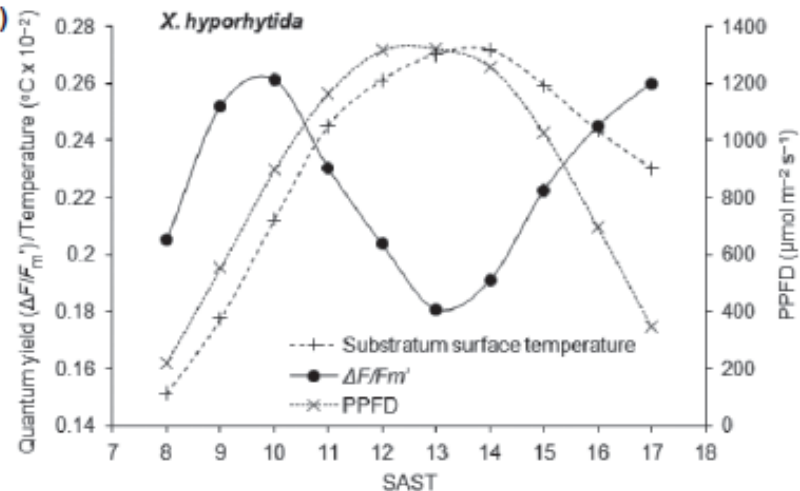

(d)

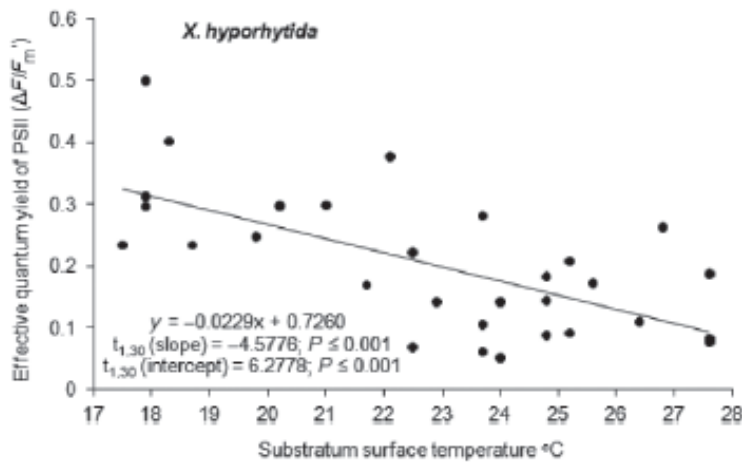

Fig 3 (a) Iterative nonlinear regression (inverse monomolecular function) of $F_{\mathrm{v}} / F_{\mathrm{m}}$ against oven exposure temperature for hydrated Xanthoparmelia hyporhytida, (b) two dimensional plot, (c) three-dimensional surface spline plot of $\Delta F / F_{\mathrm{m}}{ }^{\prime}$ against substrate surface air temperature and photosynthetic photon flux density (PPFD) (annual averages) for hydrated X. hyporhytida and (d) linearregression of $\Delta F / F_{\mathrm{m}}$ at photosynthetic saturating PPFD's $\geq 11,000 \mu \mathrm{mol} \mathrm{m}^{-2} \mathrm{~s}^{-1}$ against substrate surface air temperatures for hydrated X. hyporhytida

\section{Field studies}

All six lichen species displayed similar diurnal photosynthetic patterns in which $\Delta F / F_{\mathrm{m}^{\prime}}$ increased with increasing substrate surface air temperature and PPFD in the early morning up to about 10 : oo SAST, depending on season, with $\mathrm{D} F / F_{\mathrm{m}}$ ' subsequently decreasing with increasing substrate surface air temperature and PPFD (Fig. 3b).

Table 1 Laboratory-derived lethal photosynthetic temperatures for hydrated lichen species from two climatically diverse sites ( $y=$ maximum photosynthetic quantum yield ' $F_{\mathrm{v}} / F_{\mathrm{m}}$ " and $x=2$-h oven exposure temperature)

\begin{tabular}{lllll}
\hline Site & Lichen species & Nonlinear regression function & $r^{2}$ & $\begin{array}{l}\text { Lethal photosynthetic } \\
\text { temperature }\end{array}$ \\
\hline Dry inland & Xanthoparmelia sp. & $y=0.8454\left(1-\mathrm{e}^{-4.8780+0.1013 x}\right)$ & $0.8888^{* * * * *}$ & 48.1 \\
& X. austroafricana & $y=0.7875\left(1-\mathrm{e}^{-6.3500+0.1338 x}\right)$ & $0.8593^{* * * *}$ & 47.5 \\
& X. hyporhytida & $y=1.1405\left(1-\mathrm{e}^{-2.5474+0.0537 x}\right)$ & $0.8196^{* * * *}$ & 47.4 \\
& Xanthomaculina hottentotta & $y=1.1024\left(1-\mathrm{e}^{-2.6885+0.0571 x}\right)$ & $0.8439^{\text {**** }}$ & 47.1 \\
Humid coastal & Teloschistes capensis & $y=0.9420\left(1-\mathrm{e}^{-4.1446+0.0934 x}\right)$ & $0.8623^{* * * *}$ & 44.4 \\
& Ramalina sp. & $y=1.1337\left(1-\mathrm{e}^{-2.6306+0.0596 x}\right)$ & $0.8697^{* * * *}$ & 44.1 \\
\hline
\end{tabular}

**** $P \leq 0.001$ 
Table 2 Field-derived lethal photosynthetic temperatures for hydrated lichen species from two climatically diverse sites $(y=$ effective photosynthetic quantum yield ' $\Delta F / F_{\mathrm{m}}$ " at photosynthetic saturating photosynthetic photon flux density (PPFD)' $\mathrm{s} \geq 11,000 \mu \mathrm{mol} \mathrm{m}{ }^{-2} \mathrm{~s}^{-1}$ and $x=$ soil surface air temperature)

\begin{tabular}{llllll}
\hline Site & Lichen species & Linear regression function & $t$-statistic (slope) & $t$-statistic (intercept) & $\begin{array}{c}\text { Lethal photosynthetic } \\
\text { temperature }\end{array}$ \\
\hline Dry inland $\mathrm{C}$ & Xanthoparmelia sp. & $y=-0.0236 x+0.7715$ & $t_{1,30}=-3.7191^{* * *}$ & $t_{1,30}=5.2559^{* * *}$ & 32.7 \\
& X. austroafricana & $y=-0.0141 x+0.4928$ & $t_{1,30}=-3.3056^{* *}$ & $t_{1,30}=4.9894^{* * *}$ & 34.9 \\
& X. hyporhytida & $y=-0.0229 x+0.7260$ & $t_{1,30}=-4.5776^{* * *}$ & $t_{1,30}=6.2778^{* * *}$ & 31.7 \\
& Xamthomaculina & $y=-0.0249 x+0.8112$ & $t_{1,30}=-4.5691^{* * *}$ & $t_{1,30}=6.4515^{* * *}$ & 32.6 \\
& hottentotta & & & & \\
Humid & Teloschistes capensis & $y=-0.0321 x+0.9282$ & $t_{1,24}=-4.5972^{* * *}$ & $t_{1,24}=5.8057^{* * *}$ & 28.9 \\
coastal & Ramalina sp. & $y=-0.0296 x+0.8603$ & $t_{1,24}=-5.0461^{* * *}$ & $t_{1,24}=6.4038^{* * *}$ & 29.1 \\
\hline
\end{tabular}

${ }^{* * *} P \leq 0.001 .{ }^{* *} P \leq 0.01$.

The lowest $\Delta F / F_{\mathrm{m}^{\prime}}$ values were generally recorded at the highest substrate surface air temperatures and PPFD's around the solar noon (13: oo SAST). This was followed by a secondary phase of elevated $\Delta F / F_{\mathrm{m}}$ ' with diminishing substrate surface air temperature and PPFD after the solar noon (Fig. 3b). Threedimensional surface plots revealed linear increases in $\Delta F / F_{\mathrm{m}^{\prime}}$ with increasing PPFD's at low substrate surface air temperatures and vice versa in all six lichen species, but at a PPFD of $\geq 11,000 \mu \mathrm{mol}$ photons $\mathrm{m}^{-2} \mathrm{~s}^{-1} \Delta F / F_{\mathrm{m}^{\prime}}$ decreased linearly with increasing sub- strate surface air temperature (Fig. 3c).

Least squares regressions of measured $\Delta F / F_{\mathrm{m}^{\prime}}$ at a PPFD of $\geq 11$,000 $\mu \mathrm{mol}$ photons $\mathrm{m}^{-2} \mathrm{~s}^{-1}$ against substrate surface air temperature (Fig. 3d) had significant $(P \leq 0.001)$ slopes and intercepts in all six lichen species (Table 2). Extrapolated lethal photosynthetic temperatures for lichens from the dry inland site (range: $31.7-34.9^{\circ} \mathrm{C}$ ) were up to $6^{\circ} \mathrm{C}$ higher than those from the more humid coastal site (range: $28.9-29.1^{\circ} \mathrm{C}$ ).

\section{Discussion}

The lethal temperature range of $44.1-48.1^{\circ} \mathrm{C}$ for photo- synthetic quantum yield extrapolated for hydrated lichens under laboratory conditions in this study was slightly lower than the lethal temperatures for photosynthetic gas exchange hitherto reported for other lichen species from southern Africa and other regions of the world. Examples include $50^{\circ} \mathrm{C}$ for hydrated Umbilicaria mammulata (Ach.) Tuck. and $55^{\circ} \mathrm{C}$ for hydrated Chondropsis semiviridis (F. Muell. ex Nyl.) Nyl. ex Cromb. (Rogers, 1971), $54^{\circ} \mathrm{C}$ for hydrated Lobaria pulmonaria (L.) Hoffm. (Gauslaa \& Solhaug, 1999), 50 and $60^{\circ} \mathrm{C}$ for hydrated Ramalina menziesii Tuck. from cool and hot sites, respectively (Larson, 1989), $50^{\circ} \mathrm{C}$ for hydrated Caloplaca elegantissima (Nyl.) Zahlbr. and $55^{\circ} \mathrm{C}$ for hydrated Teloschistes capensis, Neofuscelia namibiensis (Elix \& T.H. Nash) and Xanthoparm- elia walteri M.D.E. Knox (Lalley \& Viles, 2006). The slightly lower lethal photosynthetic temperatures measured in this study were likely due to heat-induced reductions in PSII electron transport commencing at temperatures much lower than the threshold for deactivation of the photosynthetic gas exchange enzyme Rubisco (Musil et al., 2009). 
Lange et al. (2006) concluded that nocturnal moisten- ing by fog or dew in coastal deserts drives a subsequent short phase of peak lichen photosynthetic activity in the early morning hours. The duration of moisture-saturated atmosphere reported to determine the length of photo- synthetic activity and distribution patterns of Teloschistes lacunosus (Rupr.) Savicz in the Tabernas Desert in Spain (Del Prado \& Sancho, 2007). In the Namib Desert, peaks in photosynthetic activity have been reported in Ramalina maciformis (Delise) Bory and Teloschistes lacunosus in the $3-\mathrm{h}$ period after sunrise, which is complemented by a short second phase of enhanced photosynthetic activity driven by increased humidity in the late afternoon (Lange et al., 1991). These diurnal patterns in photosynthetic activity are typical for crustose and foliose lichens from the Negev Desert (Lange, 1970), for lichens from arid and semi-arid Mediterranean climates (Lange et al., 1985; Kappen, 1988) and for lichens from temperate climates (Lange, 2003). Similarly, in this study, hydrated lichens displayed an increased $\Delta F / F_{\mathrm{m}^{\prime}}$ in the early morning, which corresponded with increasing substrate surface air temperature and PPFD up to about 10 : oo SAST with a subsequent decline in $\Delta F / F_{\mathrm{m}^{\prime}}$ and increasing substrate surface air temperature and PPFD towards the solar noon.

The observed linear decline in $\Delta F / F_{\mathrm{m}}$ ' with increasing substrate surface air temperature at a saturating PPFD of $\geq 11$, $000 \mu \mathrm{mol}$ photons $\mathrm{m}^{-2} \mathrm{~s}^{-1}$ in all six lichen species examined indicated an additive effect of high PPFD and high temperature on PSII damage. This was evident from the up to $15^{\circ} \mathrm{C}$ lower extrapolated lethal temperatures for lichen photosynthetic quantum yield at a PPFD of $\geq 11,000 \mu \mathrm{mol}$ photons $\mathrm{m}^{-2} \mathrm{~s}^{-1}$ under natural conditions (range: $28.9-34.9^{\circ} \mathrm{C}$ ) than in the dark under laboratory conditions (range: 44.1-48.1 ${ }^{\circ} \mathrm{C}$ ). Similarly, Gauslaa \& Solhaug (1999) reported that a high PPFD of $1000 \mu \mathrm{mol}$ photons $\mathrm{m}^{-2} \mathrm{~s}^{-1}$ produced about the same reduction in photosynthetic quantum yield in $L$. pumonaria at $18^{\circ} \mathrm{C}$ as at $38^{\circ} \mathrm{C}$ in the dark, and at an irradiance of $1000 \mu \mathrm{mol}$ photons $\mathrm{m}^{-2} \mathrm{~s}^{-1}$, equivalent to $38^{\circ} \mathrm{C}$ in the dry lichen thallus, produced more damage to PSII than the same temperature did in the dark. High light intensities have been reported to induce severe and long-lasting photoinhibition in lichens from shaded forest habitats (Gauslaa \& Solhaug, 1996, 2000). However, photoinhibi- tion at high light intensities is considered less severe in lichens from sunlit habitats, which display an acclimation of several fluorescence parameters including $\Delta F / F_{\mathrm{m}^{\prime}}$ to seasonal changes in solar radiation. This acclimation achieved through the regulation of the UV-B-induced sun- screening cortical lichen secondary compound parietin located above the algal layer (Solhaug et al., 2003) in proportion to the seasonally changing sun exposure, the parietin reduces but not entirely eliminates photoinhibition of the photobiont (Solhaug \& Gauslaa, 1996).

Comparison of laboratory and field-derived lethal tem- perature thresholds for lichen photosynthetic quantum yield with a 27-year meteorological record of monthly average daily maximum temperatures and temperature extremes at the two study sites (Fig. 4a,b) revealed that the extrapolated lethal temperatures for lichen photosynthetic quantum yield were appreciably 
exceeded only by recorded temperature extremes during summer. Consequently, only under atypical conditions of lichen exposure in a hydrated state to temperature extremes at high midday solar irradiances during summer could lethal photosynthetic thresholds in sensitive lichen species be potentially exceeded, but whether the increased frequency of such conditions with climate warming would lead to increased likelihood of lichen mortality is debatable. This is because in moist lichens, the rate of water loss (Gauslaa \& Solhaug, 1998) and consequent evaporative cooling is high so that heat damage is less probable under natural conditions (Hoffman \& Gates, 1970). Also, high light-exposed hydrated lichen thalli have been reported to exhibit a rapid recovery of photosynthetic quantum yield in the dark (Gauslaa \& Solhaug, 1999).

Further studies are required to establish whether lethal photosynthetic thresholds of lichens from summer rain- fall regions where they are frequently exposed in a hydrated state to high midday temperatures and solar irradiances do exceed those from arid winter rainfall regions.
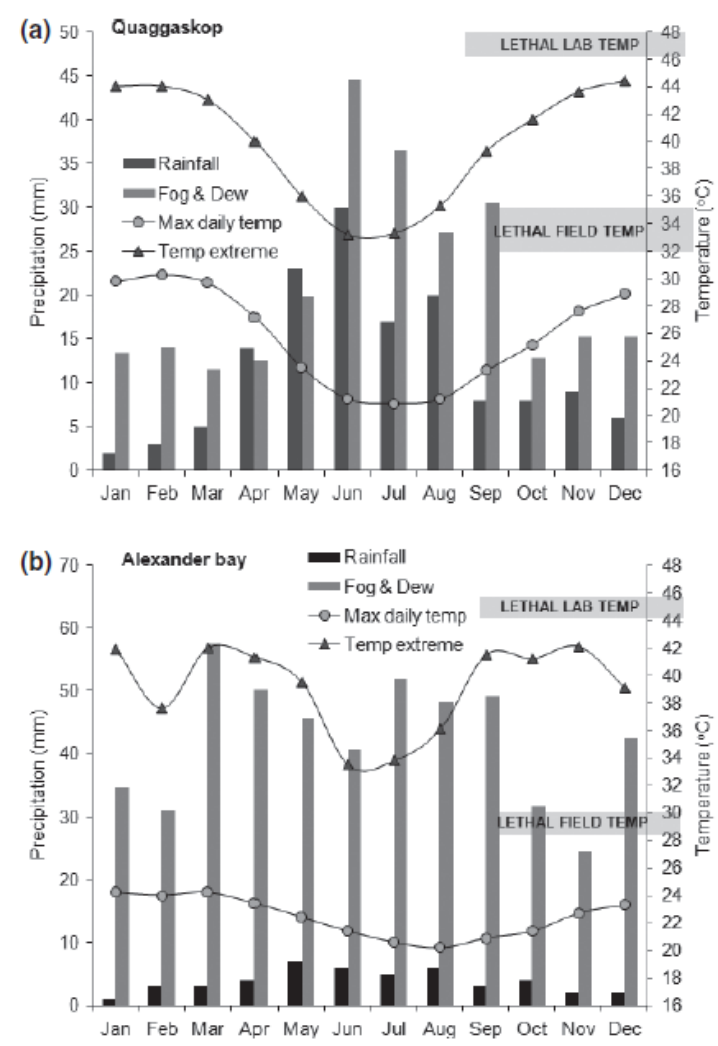

Fig 4 Monthly rainfall, fog and dew precipitation, average daily maximum temperatures and temperature extremes (1957-1984) at (a) dry inland site and (b) humid coastal site. Shaded areas indicate measured lethal photosynthetic temperatures for the dominant epilithic lichens at the two sites under laboratory and field conditions 


\section{Acknowledgements}

Mr S. Snyders provided technical support and Prof. Rambold (Bayreuth) TLC facilities for lichen identification. The study was funded by the South African National Biodiversity Institute and partly subsidized by BIOTA (Phase III) programme financed by the German Federal Ministry of Education and Research (Promotion number 01LCo624A2)1LCo624A2). 


\section{References}

Aptroot, A. \& van Herk, C.M. (2007) Further evidence of the effects of global warming on lichens, particularly those with Trentepohlia phycobionts. Environ. Pollut. 146, 293-298.

Causton, D.R. \& Dale, M.P. (1990) The monomolecular and rectangular hyperbola as empirical models of the response photosynthetic rate to photon flux density, with applications to three Veronica species. Ann. Bot. 65, 389-394.

Del Prado, R. \& Sancho, L.G. (2007) Dew as a key factor for the distribution pattern of the lichen species Teloschistes lacunosus in the Tabernas Desert (Spain). Flora 202, 417-428.

Dodge, C.W. (1971) Some lichens of tropical Africa V. Lecanoraceae to Physciaceae. Beihefte zur Nova Hedwigia 38, 1-225.

Gauslaa, Y. \& Solhaug, K.A. (1996) Differences in the susceptibility to light stress between epiphytic lichens of ancient and young boreal forest stands. Funct. Ecol. 10, 344-354.

Gauslaa, Y. \& Solhaug, K.A. (1998) The significance of thallus size for the water economy of the cyanobacterial old-forest lichen Degelia plumbea. Oecologia 116, 76-84.

Gauslaa, Y. \& Solhaug, K.A. (1999) High-light damage in air dry thalli of the old forest lichen Lobaria pulmonaria - interactions of irradiance, exposure duration of light and high temperature. J. Exp. Bot. 50, 697-705.

Gauslaa, Y. \& Solhaug, K.A. (2000) High-light-intensity damage to the foliose lichen Lobaria pulmonaria within a natural forest: the applicability of chlorophyll fluorescence methods. Lichenologist 32, 271-289.

Hảjek, J., Barták, M. \& Gloser, J. (2001) Effects of thallus temperature and hydration on photosynthetic parameters of Cetraria islandica from contrasting habitats. Photosynthetica 39, 427-435.

Hale, M.E. (1990) A synopsis of the lichen genus Xanthoparmelia (Vainio) Hale (Ascomycotina, Parmeliaceae). Smithsonian Contributions to Botany 74, 1250.

Hoffman, G.R. \& Gates, D.M. (1970) An energy budget to the study of water loss in cryptogams. Bull. Torrey Bot. Club 97, 361-366.

Hulme, M., Doherty, R., Ngara, T., New, M. \& Lister, D. (2001) African climate change: 1900-2100. Climate Res. 17, 145-168.

Insarov, G. \& Insarova, I. (2002) Long term monitoring of the response of lichen communities to climate change in the Central Negev Highlands (Israel). Bibliotheca lichenological 82, 209-220.

IPCC. (2007) The Scientific basis. In: Contribution of Working Group 1 to the Fourth Assessment Report of the Intergovernmental Panel on Climate Change. (Eds S. Solomon, D. Qin, M. Manning, Z. Chen,

M. Marquis, K.B. Averyt, M. Tignor and H.L. Miller). Cambridge University Press, Cambridge.

Kappen, L. (1988) Ecophysiological relationships in different climatic regions. In: Handbook oflichenology(Ed. M. Galun). CRC- Press, Boca Raton, Florida. 
Lalley, J.S. \& Viles, H.A. (2006) Do vehicle track disturbances affect the productivity of soil-growing lichens in a fog desert? Funct. Ecol. 20, 548556.

Lange, O.L. (1970) Experimentell-ökologische Untersuchungen an Flechten der Negev-Wüste, I. $\mathrm{CO}_{2}$-Gaswechsel von Ramalina maciformis (Del.) Bory am natürlichen Standort während der sommerlichen Trockenperiode. Flora 159, $36-62$.

Lange, O.L. (2003) Photosynthetic productivity of the epilithic lichen Lecanora muralis: long-term field monitoring of $\mathrm{CO}_{2}$ exchange and its physiological interpretation. II. Diel and seasonal patterns of net photosynthesis and respiration. Flora 198, 55-70.

Lange, O.L., Belnap, J. \& Reichenberger, H. (1998) Photosynthesis of the cyanobacterial soil-crust lichen Collema tenax from arid lands in southern Utah, USA: role of water content on light and temperature responses of $\mathrm{CO}_{2}$ exchange. Funct. Ecol. 12, 195-202.

Lange, O.L., Tenhunen, J.D., Harley, P.C. \& Walz, H. (1985) Method for field measurements of $\mathrm{CO}_{2}$-exchange. The diurnal changes in net photosynthesis and photosynthetic capacity of lichens under Mediterranean climatic conditions. In: Lichen Physiology and Cell Biology (Ed. D.H. Brown). Plenum Press, London.

Lange, O.L., Meyer, A., Ullmann, I. \& Zellner, H. (1991) Mikroklima, Wassergehalt und Photosynthese von Flechten in der küstennahen Nebelzone der Namib-Wüste: messungen während der herbstlichen Witterungsperiode. Flora 185, 233-266.

Lange, O.L., Green, A.T.G., Melze, B., Meyer, A. \& Zellner, H. (2006) Water relations and $\mathrm{CO}_{2}$ exchange of the terrestrial lichen Teloschistes capensis in the Namib fog desert: measurements during two seasons in the field and under controlled conditions. Flora 201, 268-280.

Larson, D.W. (1989) Differential heat sensitivity amongst four populations of the lichen Ramalina menziesii (Tayl). New Phytol. 111, 73-79.

MacKellar, N.C., Hewitson, B.C. \& Tadross, M.A. (2007) Namaqualand's climate: recent historical changes and future scenarios. J. Arid Environ. 70, 604614.

Maphangwa, K.W., Musil, C.F., Raitt, L. \& Zedda, L. (2011) Experimental climate warming decreases photosynthetic efficiency of lichens in an arid South African ecosystem. Oecologia 169, 257. 